\title{
Contents volume 85
}

\section{Contents volume 85 , No. 1}

Editorial

Modelling the effect of water-table management on $\mathrm{CO}_{2}$ and $\mathrm{CH}_{4}$ fluxes from peat soils

J. van Huissteden, R. van den Bos \& I. Marticorena Alvarez

Integrated chronostratigraphy of the Pliocene-Pleistocene interval and its relation

to the regional stratigraphical stages in the southern North Sea region

G. Kuhlmann, C.G. Langereis, D. Munsterman, R.-J. van Leeuwen, R. Verreussel,

J.E. Meulenkamp \& Th.E. Wong

Woodlands of the past - The excavation of wetland woods at Zwolle-Stadshagen

(the Netherlands): Reconstruction of the wetland wood in its environmental context

M.J. Kooistra, L.I. Kooistra, P. van Rijn \& U. Sass-Klaassen

Woodlands of the past - The excavation of wetland woods at Zwolle-Stadshagen

(the Netherlands): Growth pattern and population dynamics of oak and ash

U. Sass-Klaassen \& E. Hanraets

Corrigendum

Contents volume 85 , No. 2

Special Issue | Tertiary evolution of the West European Platform: syn-kinematic stratigraphy and palaeogeography

Preface

W.J.E. van de Graaff

Kinematic sequence stratigraphy of the European Cenozoic Rift System and Alpine Foreland Basin: correlation with Mediterranean and Atlantic plate-boundary events

W. Sissingh

Syn-kinematic palaeogeographic evolution of the West European Platform:

correlation with Alpine plate collision and foreland deformation

W. Sissingh

8 Enclosures 


\section{Contents volume 85 , No. 3}

3D reconstruction of salt movements within the deepest post-Permian structure of the Central European Basin System - the Glueckstadt Graben

Y. Maystrenko, U. Bayer \& M. Scheck-Wenderoth

A Lateglacial palaeosol cover in the Altdarss area, southern Baltic Sea coast (northeast Germany): investigations on pedology, geochronology and botany

K. Kaiser, A. Barthelmes, S. Czakó Pap, A. Hilgers, W. Janke, P. Kühn \& M. Theuerkauf

New stratigraphic insights in the 'Late Jurassic' of the Southern Central North Sea Graben and Terschelling Basin (Dutch Offshore) and related exploration potential

0.A. Abbink, H.F. Mijnlieff, D.K. Munsterman \& R.M.C.H. Verreussel

Geo(Im)pulse | Caprovis savinii (Bovidae, Mammalia) rediscovered: horn core finds of an Early Pleistocene antelope from the North Sea floor

B. De Wilde

\section{Contents volume 85 , No. 4}

Subsurface structure of the Netherlands - results of recent onshore and

offshore mapping

E.J.T. Duin, J.C. Doornenbal, R.H.B. Rijkers, J.W. Verbeek \& Th.E. Wong

A comprehensive seismic velocity model for the Netherlands based on lithostratigraphic layers

W. van Dalfsen, J.C. Doornenbal, S. Dortland \& J.L. Gunnink

Geo(Im)pulse | A subrosion pipe fill in the Lower Muschelkalk, Winterswijk Quarry, Eastern Netherlands

H.W. Oosterink, Th. Simon, H. Hagdorn \& H. Winkelhorst 